\title{
Does Trade Openness Matter for Economic Growth in Niger?
}

\author{
Badamassi Aboubacar1, Deyi Xu1, Amadou Maiga Ousseini2 \\ ${ }^{1}$ School of Economics and Management, China University of Geosciences, Wuhan, China \\ ${ }^{2}$ School of Economics and Trade, Hunan University, Changsha, China \\ Email: aboubacarbadamassi@yahoo.fr, xdy@cug.edu.cn, Ousseini22000@yahoo.fr
}

Received 26 November 2014; revised 10 December 2014; accepted 25 December 2014

Copyright @ 2014 by authors and Scientific Research Publishing Inc.

This work is licensed under the Creative Commons Attribution International License (CC BY).

http://creativecommons.org/licenses/by/4.0/

(c) ()

\section{Abstract}

The trade openness is one of the most important determinants of a country's relative level of economic health. It plays a vital role for most free market economies in the world. This research is an attempt to investigate, particularly, the impact of the trade openness on the economic growth in Niger; and generally, the relationship between all the variables under study. Four (4) variables namely real economic growth rate represented by real gross domestic product growth rate (GDPGR), trade openness (TRDOP), real exchange rate (REEXR) and foreign direct investment (FDI) have been considered in the model. The paper used time series data covering the period from 1980 to 2013 as well as time series methods for the econometric analyses. The results show that there exists a long term relationship between all the variables; the independent variables affects the economic growth in the short-run; only the trade openness and the real exchange rate influence economic growth unidirectionally; except foreign direct investment (FDI), all the variables have explanatory power on economic growth in Niger. The implication of this study is that the trade openness has been efficient to spur the economic growth in Niger over the period of study. Therefore, it is a key indicator which the government should care about.

\section{Keywords}

Trade Openness, Economic Growth Rate, Time Series, Niger

\section{Introduction}

International trade, also called foreign trade occurs when goods and services are exchanged across national boundaries. Nowadays, it goes beyond this scope of definition, it includes some cross border activities such as overseas investment and contracted projects. 
Whether and how trade openness influences economic growth has for long been an interesting point of research for development economists. However, the abundant literature concerning this issue still remains controversial. Although, the tendency is that good international trade policies are in favor of spurring economic growth; nevertheless, it is not a sufficient condition for economic growth and development. Alfred Marshall stated that "The causes which determine the economic progress of nations belong to the study of international trade". Moreover, trade openness, by increasing the size of the market, allows economies to better capture the potential benefits from increasing returns to scale and exploit economies of specialization (See, e.g., [1]-[3]). Further, D. H. Robertson (1938) described trade as an "engine" of growth.

In order to promote the world trade that is expected to enhance the economic growth, the world trade organization (WTO) was established in 1993 which replaced the general agreement on tariffs and trade (GATT) established in 1947. Therefore, it is clear that trade is a key determinant in improving the welfare (growth) of economies. In this era of globalization and trade liberalization, Niger joined many regional and international trade agreements such as West African economic and monetary union (WAEMU), economic community of West African states (ECOWAS), world trade organization (WTO), etc..., having an objective to create free trade zones by removing trade barriers. The policy response of such economic partnership agreements on trade policy is to remove trade barriers, reduce tariffs and embark on outward oriented trade policies which foster economic growth and alleviate poverty. For many years, improvements toward trade and investment policies are being observed in Niger and empirical works concerning the existing link between trade openness and economic growth on the specific case of the country are scarce; hence, in light of the preceding information, it is necessary to explore the trade openness and economic growth nexus in Niger, justifying our interest for this research.

The main objectives of this study are: to investigate the relationship between trade openness and economic growth; then to find the direction of the relationship; and finally to what extent, if it does, trade openness influences economic growth?

The remaining content of this paper is divided into four (4) sections. The second section covers the review of previous works; that is the literature review. The data, methodology as well as the econometric analyses are discussed in the third section. Finally, the fourth section comprises the conclusion while the last part concerns the recommendations and limitations of the research.

\section{Literature Review}

The link between trade openness and economic growth is a highly debated topic in the growth and development literature; but still, it is far from being resolved.

The theory of comparative advantage developed by David Ricardo can be considered as the root and the traditional explanations of how trade promotes economic growth. Further, other famous theories such as HechsherOhlin's theory of factor proportions, Stolper-Samuelson and Rybzsnski effects, "trade is the engine of economic growth" theory of D. H. Robertson Morrison arose to enlighten this issue of interest. In fact, all these trade theories predict that an economy will tend to be relatively effective at producing goods that are intensive in the factors with which the country is relatively well endowed. In other words, comparative advantage provides that when nations specialize, they become more efficient in producing a product (a service), and thus if they can trade for their other needs, they and the world will benefit.

As the theoretical literature which could not provide a clear picture on the trade openness-economic growth nexus, the empirical literature is also still an open question. In order to determine the potential relationship and, direction of causality if any, between trade openness and economic growth, an extensive range of research has surfaced.

In his investigation of the relationship between globalization and growth, Uwatt [4] used panel data for forty one (41) African countries covering the period 1980-1999. He recommended that African nations elaborate meaningful policies to face the demands of trade openness which will increase capital inflows and promote trade. Sachs and Warner [5] found that, in the 1970s and 1980s, the annual economic growth rate of the opened countries to trade was about $4.5 \%$ while that of the closed countries was $0.7 \%$. Hoeffler [6] confirmed that openness to trade has a positive and significant effect on economic growth through increased investment based on the binary measure of Sachs and Warner. Moreover, Alege and Ogun investigated the relationship between openness to trade and industrialization by checking the influence of some indices of globalization such as degree of openness, volume of trade, inflow of foreign direct investment and increased technological innovations on aggregate 
manufacturing production in Nigeria. His work's results have shown that openness to trade, volume of trade, and increased information technology (IT) impact the level of manufacturing output significantly. This conclusion is consistent with that of Akinlo [7] who found that, in Sub-Saharan African countries, a 1\% growth in exports increases stock market by $0.19 \%$ considering growth rate of exports and FDI as proxy for degree of openness. Dollar [5], Edwards [8], Barro and Sala-i-Martin [9] [10], Greenaway et al. [11], and Vamvakidis argued that trade openness spurs economic growth by using cross-country regressions.

Furthermore, in their paper aimed to identify, in the context of the relationship between openness and growth, factors that can account for the poor growth performance of Sub-Saharan African (SSA) countries, Mbabazi J., et al. [12] included inequality as a broad measure of policy distortions. They used cross-section and panel econometric techniques to investigate the links between growth, inequality and openness for a sample of 44 developing countries over the period 1970-1995 and made four main conclusions.” First, within the sample, there is a low correlation between initial GDP and inequality. Second, inequality appears to have a robust negative effect on growth in the long run but not in the short run. Third, there is consistent evidence that openness is positively associated with growth, and some evidence that trade liberalization tends to offset or dampens the negative effect of inequality on growth. Finally, Africa does appear to be different; the especially poor SSA growth performance can be explained by the combination of low levels of openness, high natural barriers to trade (especially high costs of transport to distant dynamic markets) and export dependence on primary commodities [12]”. Harrison used cross sectional and panel data for the period 1960-1987 and examined the link between openness and economic growth in developing countries using augmented production function. He concluded that longer time series data favor more evidence of the positive impact of openness on economic growth; hence notifying that the time period chosen for the analyses is very important.

An empirical work to examine the relationship between financial development, trade openness and economic growth in Japan using data from 1960 to 2003 is made by Soukhakian [13]. The findings revealed the existence of a long run relationship between financial development, trade and economic growth in Japan except between domestic credit, trade and growth. And concerning the causality, the economic growth appears to Granger-cause openness, thus supporting the growth-driven trade hypothesis for Japan.

To investigate the long-term nexus between exports and domestic economic growth in Saudi Arabia for the period 1970-2005, Hassan (2007) used Vector Auto-Regression (VAR), Impulse Response Function (IFR) and Granger-causality test. The results indicated that the export sector had a significant impact on the economic growth and a positive effect on other economic activities in the long run. Using VAR and VECM, Mustafa [14] examined the relationship between foreign trade and economic growth in Turkey by working with quarterly data on GDP, export and import covering the period 1987-2007. The results suggested that GDP growth did not significantly depend on the export growth in the short run.

Rodiguez and Rodrik [15] reported that there is little or no evidence that openness to trade policies contribute significantly to economic growth.

Dudley and Karski [16] investigated whether the degree of openness affect economic growth using panel regression during a period of 20 years from 1969-1989 for ten developing countries. Their results show that in 3 of the 10 countries, the degree of openness has a positive effect, on another 3 it has a negative effect and has no effect on the remaining 4 .

\section{Data, Methodology and Econometric Results}

\subsection{Data}

Time series data on four key macroeconomic variables, namely, real gross domestic product growth rate (GDPGR), trade openness (TRDOP), real effective exchange rate (REEXR) and foreign direct investment (FDI) are used to carry out the analyses. The data are collected on annual basis covering the period from 1980 to 2013 and are extracted from the United Nations Conference on trade and Development (UNCTAD) data base [17]. The ratio of the sum of the total exports and imports in goods and services and the gross domestic product [(exports + imports)/GDP] represents the proxy for the variable of trade openness. TRDOP is used because it is the main explanatory variable of the study whose effect on GDPGR is to be assessed. The REEXR is expected to play a crucial role in the economic growth of Niger as the country is a small open economy, hence choosing it as a control variable will help avoiding the omitting variable bias problem. As a rich country in natural resources, also, FDI is very important for its economy, thus we used this variable based on the same reasons with REEXR. 


\subsection{Methodology}

A model based on the four (4) variables previously mentioned, is built in order to assess the link between them. It assumed GDPGR as a function of TRDOP, REEXR and FDI.

The model is expressed as follows:

$$
\left.\mathrm{GDPGR}_{\mathrm{t}}=\mathrm{F}_{\mathrm{TTRDOP}}, \mathrm{REEXR}_{\mathrm{t}}, \mathrm{FDI}_{\mathrm{t}}\right] \text {, where } \mathrm{t} \text { denotes the time. }
$$

To estimate properly the parameters and facilitate the interpretation, a logarithmic transformation is made to the variables which do not contain negative and/or zero values, precisely TRDOP and REEXR. Thus, the final model is:

$$
\Delta \mathrm{GDPGR}=\alpha+\beta_{1} \Delta \operatorname{lnTRDOP}+\beta_{2} \Delta \operatorname{lnREEXR}+\beta_{3} \Delta \mathrm{FDI}+\varepsilon
$$

Then, the following methods are applied:

The Augmented Dickey-Fuller test (ADF) [18]: to check whether the series are stationary or not;

A time series variable, $Y_{t}$, is stationary if:

1. The expected value of $Y_{t}, E\left(Y_{t}\right)$ is the same for all values of $t$;

2. The variance of $Y_{t}$, $\operatorname{Var}\left(Y_{t}\right)$ is finite and the same for all values of $t$;

3. $\operatorname{Cov}\left(\mathrm{Y}_{\mathrm{t}}, \mathrm{Y}_{\mathrm{t}-\mathrm{s}}\right)$ depends only on $\mathrm{s}$, but not on $\mathrm{t}$.

These concepts capture the ideas that the basic statistical properties of the model (i.e. means, variances, and covariances) do not change over time.

There are many unit root tests but here we used the Augmented Dickey-Fuller test. It performs the test that a variable follows a unit-root process. The null hypothesis is that the variable contains a unit root. So, if the P-value of the coefficient of a variable is less than $5 \%$ level of significance (P-value $<0.05$ ), we reject the null hypothesis and conclude that the variable is stationary otherwise we accept it.

The Johansen Cointegration test: to check the existence of a long-run relationship between the variables by determining the presence and the number of cointegrating equations;

The Johansen's trace statistics method for determining $r$, the number of cointegrating equations used here can be interpreted as being an estimator $\hat{\mathrm{r}}$ of the true number of cointegrating equations $\mathrm{r}$. The method starts testing at $\mathrm{r}=0$ and accepts $\hat{\mathrm{r}}$ the first value of $\mathrm{r}$ for which the trace statistic fails to reject the null hypothesis (if the trace statistic is less than its $5 \%$ critical value) that there are no more than $r$ cointegrating relations. Unlike the Engel and Granger test, the Johansen-Juselius approach provides not only a test for co-integration but also reveals the number of co-integration relationships; thus, justifying our choice of the Johansen-Juselius cointegration test.

The Vector Error Correction Model: to characterize the long-run and short-run dynamics;

The VECM consists to observe long-term and short-term relationships among all variables.

In order to characterize the long-run dynamics, we use the following Vector Error correction model:

$$
\Delta \mathrm{x}_{\mathrm{t}}=\mathrm{c}+\sum_{i=1}^{k-1} \Gamma i \Delta x_{\mathrm{t}-1}+\prod x_{\mathrm{t}-1}+\varepsilon_{\mathrm{t}}
$$

With $x_{t}=\left[G D P G R_{t} T_{R D O P} R_{t} E E X R_{t} F_{t}\right]$, Where $t$ stands for the time and the remaining variables are as defined above.

The Granger causality test [19]: to investigate the direction of the causality.

It established the sense of causality between dependent and independent variables. Performing Granger causality test requires that all the variables are stationary. So, for this reason we transformed the variables to the first order difference before running the test. The hypotheses to test are:

$\mathrm{HO}$ : the independent variable does not granger cause the dependent variable

H1: the independent variable does granger cause the dependent variable

The variable $x$ is said to Granger "cause" $y$ if we reject H0.

\subsection{Results of the Econometric Analyses}

\subsubsection{Unit Root Test Results}

The output of this test indicates that, only GDPGR and FDI are stationary at level; but after the first difference, all the variables become stationary (since P-values $<0.05$ ). The results are summarized in Table 1 which justified our further analyses. 
Table 1. Augmented dickey-fuller test's results.

\begin{tabular}{ccccc}
\hline Variables & ADF Test Statistic & $\begin{array}{c}\mathbf{5 \%} \text { Critical Value of ADF } \\
\text { Test Statistic }\end{array}$ & $\begin{array}{c}\text { P-Values (5\% Level of } \\
\text { Significance) }\end{array}$ & $\begin{array}{c}\text { Order of Remarks } \\
\text { Integration }\end{array}$ \\
\hline DGDPGR & -5.920115 & -2.963972 & $0.0000^{*}$ & $\mathrm{I}(1) 1^{\text {st }}$ order Difference stationary \\
DLnTRDOP & -6.130508 & -2.957110 & $0.0000^{*}$ & $\mathrm{I}(1) 1^{\text {st }}$ order Difference stationary \\
DLnREEXR & -6.010155 & -2.957110 & $0.0000^{*}$ & I(1) $1^{\text {st }}$ order Difference stationary \\
DFDI & $-\mathbf{4 . 1 2 1 6 2 6}$ & $-\mathbf{2 . 9 6 3 9 7 2}$ & $\mathbf{0 . 0 0 3 3}^{*}$ & $\mathbf{I}(\mathbf{1}) \mathbf{1}^{\text {st }}$ order Difference stationary \\
\hline
\end{tabular}

${ }^{*}$ Stationary at 5\% level of significance.

\subsubsection{Co Integration Test Results}

Estimating a co integrating rank necessitates knowing how many lags should be used. For this reason we performed a lag selection-order criteria and the output is presented in Table 2. It reports the sequential modified LR test statistic (LR), Final Prediction Error (FPE), Akaike's Information Criterion (AIC), Schwarz's Information Criterion (SC), and the Hannan and Quinn Information Criterion (HQ) lag order selection statistic. Here, we consider FPE and AIC tests and select three (3) lags for the model as indicated by the " "” in the output table.

Johansen's multivariate cointegration test results, based on trace statistic and maximum Eigen value statistic, both reveal the existence of one cointegrating equation among the variables (since "At most 1" is the first value for which the trace statistic 26.40397 is less than its $5 \%$ critical value of 29.79707). Since the variables are found to be cointegrated, thus, we conclude that there exists a long-run relationship between GDPGR, InTRDOP, lnREEXR and FDI. See Table 3, Table 4.

The above cointegration tables indicate that all the variables have long run relationship.

\subsubsection{Granger Causality Test Results}

It investigated the sense of causality between all the different pairs of variables. The results are presented in Table 5. However, an examination of the results shows that there is no bi-directional causality among the variables and; only two unidirectional causalities exist running from TRDOP to GDPGR and from REEXR to GDPGR since the P-values $(0.0455,0.0421)$ are less than 0.05 . Hence, this leads us to the conclusion that TRDOP and REEXR granger causes GDPGR which matched with our expected findings.

\subsubsection{Regression Results}

Since we previously found that our variables are cointegrated and the R-Square (0.628416) is less than the Durbin-Watson statistic (2.765477) in Table 6; so, we don't need to worry about the spurious regression problem in our estimates. Therefore, we run the regression model and proceed to the interpretation of the results.

The information in Table 6 reveals that with the exception of the FDI, all the coefficients are statistically significant since their P-values are less than 0.05 .

Confirming the theory, the degree of trade openness has a positive effect on the economic growth. An increase of the TRDOP, on average, by $1 \%$ increases the economic growth by $16.73851 \%$, ceteris paribus .This means that as long as Niger was opening more to international trade during the period of study, its economy was likely to grow, in other words the openness to trade enhanced the economic growth in Niger. This early stage increase in output growth as a result of trade openness can be attributed to the deployed efforts by government to develop some infrastructures during the uranium boom period of the 1970's and early 1980's.

As expected, the results showed that REEXR has a positive effect on economic growth meaning that when the REEXR increases (depreciates) economic growth also increases and when REEXR decreases (appreciates), economic growth decreases. The depreciation of the real exchange rate of the FCFA, in the long-run increases the economic growth rate, holding the other variables constant. The change in the economic growth rate increases by $8.981520 \%$ for one percent increase in real effective exchange rate.

59.84143 is the constant and represent the value of the growth rate when all the variables are zero.

Surprisingly, the coefficient FDI has a negative impact on economic growth and is insignificant. This insignificance may be due to the fact that; in Niger more than $70 \%$ of the amount of money invested as FDI are not spent in the country.

Therefore, in this study, it follows that TRDOP and REEXR are the key variables affecting GDPGR. 
Table 2. Lag selection-order criteria before cointegration.

\begin{tabular}{ccccccc}
\hline Lag & LogL & LR & FPE & AIC & SC & HQ \\
\hline 0 & -283.5895 & NA & 1343.108 & 18.55416 & 18.73919 & 18.61448 \\
1 & -194.6823 & 149.1346 & 12.30901 & 13.85047 & $14.77563^{*}$ & $14.15205^{*}$ \\
2 & -175.2224 & $27.62055^{*}$ & 10.42817 & 13.62725 & 15.29253 & 14.17009 \\
3 & -156.2736 & 22.00503 & $10.03353^{*}$ & $13.43701^{*}$ & 15.84241 & 14.22111 \\
\hline
\end{tabular}

*indicates lag order selected by the criterion; LR: Sequential modified LR test statistic (each test at $5 \%$ level); FPE: Final prediction error; AIC: Akaike information criterion; SC: Schwarz information criterion; HQ: Hannan-Quinn information criterion.

Table 3. Unrestricted cointegration rank test (trace).

\begin{tabular}{ccccc}
\hline Hypothesized & \multicolumn{3}{c}{ Trace } & 0.05 \\
\hline No. of CE(s) & Eigenvalue & Statistic & Critical Value & Prob. $^{* *}$ \\
\hline None $^{*}$ & 0.649200 & 57.83017 & 47.85613 & 0.0044 \\
At most 1 & 0.478957 & 26.40397 & 29.79707 & 0.1171 \\
At most 2 & 0.129168 & 6.846289 & 15.49471 & 0.5956 \\
At most 3 & 0.085981 & 2.697117 & 3.841466 & 0.1005 \\
\hline
\end{tabular}

Trace test indicates 1 cointegrating eqn(s) at the 0.05 level; ${ }^{*}$ denotes rejection of the hypothesis at the 0.05 level; ** MacKinnon-Haug-Michelis (1999) P-values.

Table 4. Unrestricted cointegration rank test (maximum eigenvalue).

\begin{tabular}{ccccc}
\hline Hypothesized & & Max-Eigen & 0.05 & \\
\hline No. of CE(s) & Eigenvalue & Statistic & Critical Value & Prob. $^{* *}$ \\
\hline None $^{*}$ & 0.649200 & 31.42621 & 27.58434 & 0.0152 \\
At most 1 & 0.478957 & 19.55768 & 21.13162 & 0.0818 \\
At most 2 & 0.129168 & 4.149172 & 14.26460 & 0.8433 \\
At most 3 & 0.085981 & 2.697117 & 3.841466 & 0.1005 \\
\hline
\end{tabular}

Max-eigenvalue test indicates 1 cointegrating eqn(s) at the 0.05 level; ${ }^{*}$ denotes rejection of the hypothesis at the 0.05 level; ${ }^{* *}$ MacKinnon-Haug-Michelis (1999) P-values.

Table 5. Granger causality test's results.

\begin{tabular}{lccc}
\hline Null Hypothesis: & Obs & F-Statistic & Prob. \\
\hline LNTRDOP does not Granger Cause GDPGR & 28 & 2.87345 & $0.0455^{*}$ \\
GDPGR does not Granger Cause LNTRDOP & & 1.69796 & 0.1896 \\
LNREEXR does not Granger Cause GDPGR & 28 & 1.07141 & $0.0421^{*}$ \\
GDPGR does not Granger Cause LNREEXR & & 0.98417 & 0.4696 \\
FDI does not Granger Cause GDPGR & 28 & 1.36864 & 0.2891 \\
GDPGR does not Granger Cause FDI & & 0.71118 & 0.6462 \\
LNREEXR does not Granger Cause LNTRDOP & 28 & 0.51722 & 0.7864 \\
LNTRDOP does not Granger Cause LNREEXR & & 1.02348 & 0.4475 \\
FDI does not Granger Cause LNTRDOP & 28 & 0.75071 & 0.6185 \\
LNTRDOP does not Granger Cause FDI & & 0.99952 & 0.4609 \\
FDI does not Granger Cause LNREEXR & & 0.40062 & 0.8672 \\
LNREEXR does not Granger Cause FDI & 28 & 0.54179 & 0.7687
\end{tabular}

*Significant at 5\% level of significance. 
Table 6. Regression’s results.

\begin{tabular}{cccc}
\hline Independent variables and the constant & Coefficients & P-values & Significant or not? \\
\hline DLnTRDOP & 16.73851 & 0.0099 & Significant \\
DLnREEXR & 8.981520 & 0.0021 & Significant \\
DFDI & -0.006490 & 0.2791 & Not Significant \\
C & $\mathbf{5 9 . 8 4 1 4 3}$ & $\mathbf{0 . 0 0 3 6}$ & Significant \\
\hline
\end{tabular}

R-Square: 0.628416; Durbin-Watson statistic: 2.765477.

\subsubsection{Vector Error Correction Model Test Results}

Table A1 in the Appendix reports the results of the VECM. From that table, the coefficient on C1 is the error correction term or the speed of adjustment towards long run equilibrium. For the system to adjust, the coefficient must have a negative sign and be significant. Thus, from our output $\mathrm{C} 1$ satisfies the condition and confirms that all the variables have long run associationship. It also indicates that the speed of adjustment or the error correction coefficient corrects the disequilibrium of the change in GDPGR very fast at a rate of 316.53\% towards long run equilibrium within one year.

All the remaining coefficients on C2, C3, C4, C5, C6, C7, C8, C9, C10, C11, C12 and C13 of the variables are short run coefficients; and C14 is the _cons (constant). However, before confirming the results of the VECM, we should test the validity of its residuals. Table A2 (Appendix) reports the results of the residuals' serial correlation based on the LM test. The results show that we cannot reject the null hypothesis (H0) that there is no serial correlation in the residuals since Prob. (0.4823) is greater than 0.05 (level of significance).

The Figure A1 (Appendix) presents the output of the Jarque-Bera test of normality of the residuals. The results suggest also that we accept the null hypothesis (H0) that the residuals are normally distributed since the Prob. (0.663257) is greater than 0.05 .

Table A3 (Appendix) shows the results of the heteroskedasticity Test (ARCH). It indicates that we fail to reject the null hypothesis (H0) that the residuals do not have ARCH effect as the Prob. (0.3979) is greater than 0.05.

Therefore, all the performed tests show that we have no doubt to validate our model.

Finally, we run Wald test to check whether the coefficients of the different independent variables and their lags jointly have short run effects on the GDPGR. The null hypotheses are: $\mathrm{C} 2=\mathrm{C} 3=\mathrm{C} 4=0 ; \mathrm{C} 5=\mathrm{C} 6=\mathrm{C} 7=0$; $\mathrm{C} 8=\mathrm{C} 9=\mathrm{C} 10=0$ and $\mathrm{C} 11=\mathrm{C} 12=\mathrm{C} 13=0$. The outputs in Tables A4-A7 (Appendix) show that none of the variables appears to be significantly affecting the GDPGR (since their Chi-square P-values 0.1247, 0.8620, 0.2994 and 0.6872 respectively are greater than 0.05 ).

\section{Conclusions}

The nexus between trade openness and economic growth in Niger is the main focus in this paper. A four variables model was built in order to investigate our main objectives' hypotheses with GDPGR as the dependent, TRDOP the independent variable and, REEXR and FDI considered as control variables.

The results of the econometric analyses reveal that:

There is a long-run relationship between the variables under study;

Only TRDOP and REEXR granger cause GDPGR;

None of the explanatory variables influences economic growth in the short-run;

Conclusively, in Niger, it appeared that TRDOP and REEXR are crucial factors to be considered with very much attention as far as the country wants to enjoy a long-run economic growth.

\section{Recommendations and Limitations}

\subsection{Recommendations}

In light of the findings, this study recommends the following policies:

\subsubsection{Provision of Adequate Infrastructural Facilities}

The government should emphasize on the provision of adequate infrastructures to help in reducing the high cost 
of transportation, providing sufficient electricity and others which constitute big obstacles for the welfare of trade activities in Niger. For instance, the revenue rose from the exports of uranium and oil can be used to develop required infrastructures.

\subsubsection{Good Exchange Rate}

The adoption of a better exchange rate mechanism: a flexible exchange rate favorable to export expansion and consistent with Niger as a small open economy will be better than the actual fixed exchange rate with the Euro.

\subsubsection{Good Fiscal Policies}

Better fiscal policies toward enhancing trade and investment should be considered in Niger because of its large dependence on foreign aid and its unfavorable geographical position (landlocked country).

\subsubsection{Fighting Informal Trade Activities}

Illegal trade activities like smuggling, drug trafficking, etc... are some major problems being faced by Niger across the borders and even within the country. Therefore, the government needs to reduce import tariffs and secure more the borders in order to discourage or prevent these underground activities.

\subsubsection{Diversification of the Economy}

Good new oriented investments' policies are needed in order to boost the exports of manufactured products instead of relying only on raw materials specifically uranium and the recently discovered oil because Niger's economy suffered a lot from international shocks such as recession and inflation due to its high dependence on the trade of these raw materials.

Diversification of trade partners is another key aspect to be considered in order to gain more from trade.

\subsubsection{Reducing Tax and Granting Subsidies}

Agriculture accounts much in the GDP of Niger, so encouraging agricultural production through subsidies or tax reduction will be of great interest for the country.

\subsection{Limitations}

In spite of the much attention given to this study, we noted, however, that it has not been left without some limitations.

We well know that, the determinants of economic growth are many but due to the unavailability of the data, we could not enlarge the research using other important variables.

Also, Future research should use more advanced econometric tools for deeper analyses.

\section{Acknowledgements}

We would like to thank the NSFC 41272362 for all its supports in carrying out this study.

\section{References}

[1] Alesina, A., et al. (2000) Economic Integration and Political Disintegration. National Bureau of Economic Research.

[2] Bond, E.W., et al. (2005) Economic Takeoffs in a Dynamic Process of Globalization. Review of International Economics, 13, 1-19. http://dx.doi.org/10.1111/j.1467-9396.2005.00489.x

[3] Romer, P.M. (1989) Growth Based on Increasing Returns Due to Specialization. The American Economic Review, 5662.

[4] Uwatt, B.U. (2004) Globalization and Economic Growth: The African Experience. Nigeria Economic Society.

[5] Sachs, J.D., et al. (1995) Economic Reform and the Process of Global Integration. Brookings Papers on Economic Activity, 1995, 1-118. http://dx.doi.org/10.2307/2534573

[6] Collier, P. (2002) Aid, Policy, and Growth in Post-Conflict Societies. World Bank Policy Research Working Paper 2902.

[7] Akinlo, E. (2003) Globalization, International Investment and Stock Market Growth in Sub-Saharan Africa. Visiting Research Fellow Monograph Series. 
[8] Edwards, S. (1998) Openness, Productivity and Growth: What Do We Really Know? The Economic Journal, 108, 383398. http://dx.doi.org/10.1111/1468-0297.00293

[9] Barro, R. and Sala-I-Martin, X. (1995) Economic Growth. Boston.

[10] Barro, R.J. and Sala-I-Martin, X. (1995) Economic Growth. McGraw Hill, New York.

[11] Haberler, G. (1988) International Trade and Economic Development. International Center for Economic Growth, San Francisco.

[12] Mbabazi, J., Milner, C. and Morrissey, O. (2006) Trade Openness, Trade Costs and Growth: Why Sub-Saharan Africa Performs Poorly. CREDIT Research Paper.

[13] Soukhakian, B. (2007) Financial Development, Trade Openness and Economic Growth in Japan: Evidence from Granger Causality Tests. International Journal of Economic Perspectives, 1, 117-126.

[14] Kahya, M. (2011) An Analysis of the Relationship between Foreign Trade and Economic Growth in Turkey over the Period 1980-2009. Unpublished Draft, School of Economics and Management, Lund University, Lund. http://www.ehl.lu.se

[15] Rodriguez, F. and Rodrik, D. (2001) Trade Policy and Economic Growth: A Skeptic's Guide to the Cross-National Evidence. In: Bernanke, B. and Rogoff, K.S., Eds., NBER Macroeconomics Annual 2000, Volume 15, The MIT Press, Cambridge, 261-338.

[16] Dudley, L. and Karski, M.B. (2001) Does the Degree of Openness of an Economy Affect Its Economic Growth? Openness and Growth: A Panel Data Analysis for Developing Countries.

[17] UNCTAD WID (2006) Country Profile: NIGER. http://unctad.org/en/Pages/Statistics.aspx/fdi/

[18] Dickey, D. and Fuller, W. (1981) Likelihood Ratio Statistics for Autoregressive Time Series with a Unit Root. Econometrica, 49, 1057-1072. http://dx.doi.org/10.2307/1912517

[19] Engle, F.R. and Granger, W.C. (1987) Co-Integration and Error Correction: Representation, Estimation and Testing. Econometrica, 55, 251-276. http://dx.doi.org/10.2307/1913236 


\section{Appendix}

Table A1. The results of the VECM.

Dependent Variable: D(GDPGR)

Method: Least Squares

Date: 10/24/14 Time: 04:23

Sample (adjusted): 19842013

Included observations: 30 after adjustments

$\mathrm{D}($ GDPGR $)=\mathrm{C}(1) *($ GDPGR $(-1)-6.79677810559 *$ LNTRDOP $(-1)+8.19881933707 * \operatorname{LNREEXR}(-1)+0.000532372717984 * \mathrm{FDI}(-1)-$ $47.6714029293)+\mathrm{C}(2) * \mathrm{D}(\mathrm{GDPGR}(-1))+\mathrm{C}(3) * \mathrm{D}(\mathrm{GDPGR}(-2))+\mathrm{C}(4) * \mathrm{D}(\operatorname{GDPGR}(-3))+\mathrm{C}(5) * \mathrm{D}(\mathrm{LNTRDOP}(-1))+$ $\mathrm{C}(6) * \mathrm{D}(\operatorname{LNTRDOP}(-2))+\mathrm{C}(7) * \mathrm{D}(\operatorname{LNTRDOP}(-3))+\mathrm{C}(8) * \mathrm{D}(\operatorname{LNREEXR}(-1))+\mathrm{C}(9) * \mathrm{D}(\operatorname{LNREEXR}(-2))+\mathrm{C}(10) * \mathrm{D}(\operatorname{LNREEXR}(-3))+$ $\mathrm{C}(11) * \mathrm{D}(\mathrm{FDI}(-1))+\mathrm{C}(12) * \mathrm{D}(\mathrm{FDI}(-2))+\mathrm{C}(13) * \mathrm{D}(\mathrm{FDI}(-3))+\mathrm{C}(14)$

\begin{tabular}{|c|c|c|c|c|}
\hline & Coefficient & Std. Error & t-Statistic & Prob. \\
\hline $\mathrm{C}(1)$ & -3.165264 & 0.783937 & -4.037652 & 0.0010 \\
\hline $\mathrm{C}(2)$ & 1.459974 & 0.643611 & 2.268410 & 0.0375 \\
\hline $\mathrm{C}(3)$ & 0.746352 & 0.422288 & 1.767403 & 0.0962 \\
\hline $\mathrm{C}(4)$ & 0.385961 & 0.253390 & 1.523185 & 0.1472 \\
\hline $\mathrm{C}(5)$ & -11.67680 & 14.79012 & -0.789500 & 0.4414 \\
\hline $\mathrm{C}(6)$ & -2.441110 & 13.31262 & -0.183368 & 0.8568 \\
\hline $\mathrm{C}(7)$ & -4.317592 & 12.24548 & -0.352586 & 0.7290 \\
\hline $\mathrm{C}(8)$ & 19.98454 & 10.80771 & 1.849101 & 0.0830 \\
\hline $\mathrm{C}(9)$ & 3.672254 & 10.70269 & 0.343115 & 0.7360 \\
\hline $\mathrm{C}(10)$ & 7.267951 & 9.792628 & 0.742186 & 0.4687 \\
\hline $\mathrm{C}(11)$ & 0.005221 & 0.013745 & 0.379868 & 0.7090 \\
\hline $\mathrm{C}(12)$ & -0.018694 & 0.016520 & -1.131585 & 0.2745 \\
\hline $\mathrm{C}(13)$ & 0.012333 & 0.012989 & 0.949525 & 0.3565 \\
\hline $\mathrm{C}(14)$ & 1.105845 & 1.145015 & 0.965790 & 0.3485 \\
\hline R-squared & 0.842298 & \multicolumn{2}{|c|}{ Mean dependent var } & 0.364955 \\
\hline Adjusted R-squared & 0.714164 & \multicolumn{2}{|c|}{ S.D. dependent var } & 7.952673 \\
\hline S.E. of regression & 4.251784 & \multicolumn{2}{|c|}{ Akaike info criterion } & 6.037279 \\
\hline Sum squared resid & 289.2427 & \multicolumn{2}{|c|}{ Schwarz criterion } & 6.691171 \\
\hline Log likelihood & -76.55919 & \multicolumn{2}{|c|}{ Hannan-Quinn criter. } & 6.246465 \\
\hline F-statistic & 6.573610 & \multicolumn{2}{|c|}{ Durbin-Watson stat } & 1.665253 \\
\hline Prob (F-statistic) & 0.000333 & & & \\
\hline
\end{tabular}

Table A2. Breusch-godfrey serial correlation LM test.

\begin{tabular}{cccc}
\hline F-statistic & 0.387360 & Prob. F(3,13) & 0.7640 \\
\hline Obs*R-squared & 2.461670 & Prob. Chi-Square(3) & 0.4823 \\
\hline
\end{tabular}




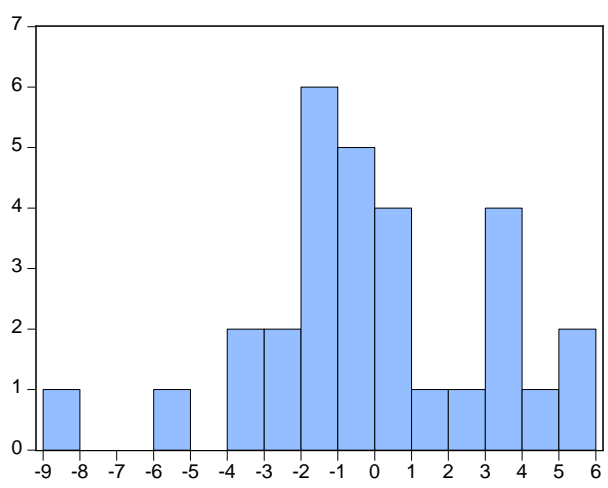

\begin{tabular}{|ll|}
\hline \multicolumn{2}{|l|}{ Series: Residuals } \\
Sample 1984 2013 \\
Observations & 30 \\
Mean & $-9.64 \mathrm{e}-16$ \\
Median & -0.127263 \\
Maximum & 5.992017 \\
Minimum & -8.492986 \\
Std. Dev. & 3.158146 \\
Skewness & -0.334506 \\
Kurtosis & 3.457573 \\
& \\
Jarque-Bera & 0.821186 \\
Probability & 0.663257 \\
\hline
\end{tabular}

Figure A1. Jarque-Bera test of normality of the residuals.

Table A3. The results of the heteroskedasticity Test (ARCH).

\begin{tabular}{cccc}
\hline \multicolumn{3}{c}{ Heteroskedasticity Test: ARCH } & \\
\hline F-Statistic & 0.943733 & Prob. F(3,23) & 0.4357 \\
Obs*R-Squared & 2.959304 & Prob. Chi-Square(3) & 0.3979 \\
\hline
\end{tabular}

Table A4. Wald test for short run impact (C2 = C3 = C4 = 0).

Wald Test:

Equation: Untitled

$\begin{array}{cccc}\text { Test Statistic } & \text { Value } & \text { df } & \text { Probability } \\ \text { F-Statistic } & 1.914749 & (3,16) & 0.1679 \\ \text { Chi-Square } & 5.744246 & 3 & 0.1247\end{array}$

Null Hypothesis Summary:

Normalized Restriction $(=0)$

$\mathrm{C}(2)$

$\mathrm{C}(3)$

$\mathrm{C}(4)$
Value

Std. Err.

1.459974

0.746352

0.385961
0.643611

0.422288

0.253390

Restrictions are linear in coefficients.

Table A5. Wald test for short run impact $(\mathrm{C} 5=\mathrm{C} 6=\mathrm{C} 7=0)$.

Wald Test:

Equation: Untitled

$\begin{array}{cccc}\text { Test Statistic } & \text { Value } & \text { df } & \text { Probability } \\ \text { F-Statistic } & 0.249200 & (3,16) & 0.8607 \\ \text { Chi-Square } & 0.747599 & 3 & 0.8620\end{array}$

Null Hypothesis Summary:

Normalized Restriction (=0)
$\mathrm{C}(5)$
C(6)
$\mathrm{C}(7)$

Value

$-11.67680$

$-2.441110$

$-4.317592$
Std. Err.

14.79012

13.31262

12.24548

Restrictions are linear in coefficients. 
Table A6. Wald test for short run impact $(\mathrm{C} 8=\mathrm{C} 9=\mathrm{C} 10=0)$.

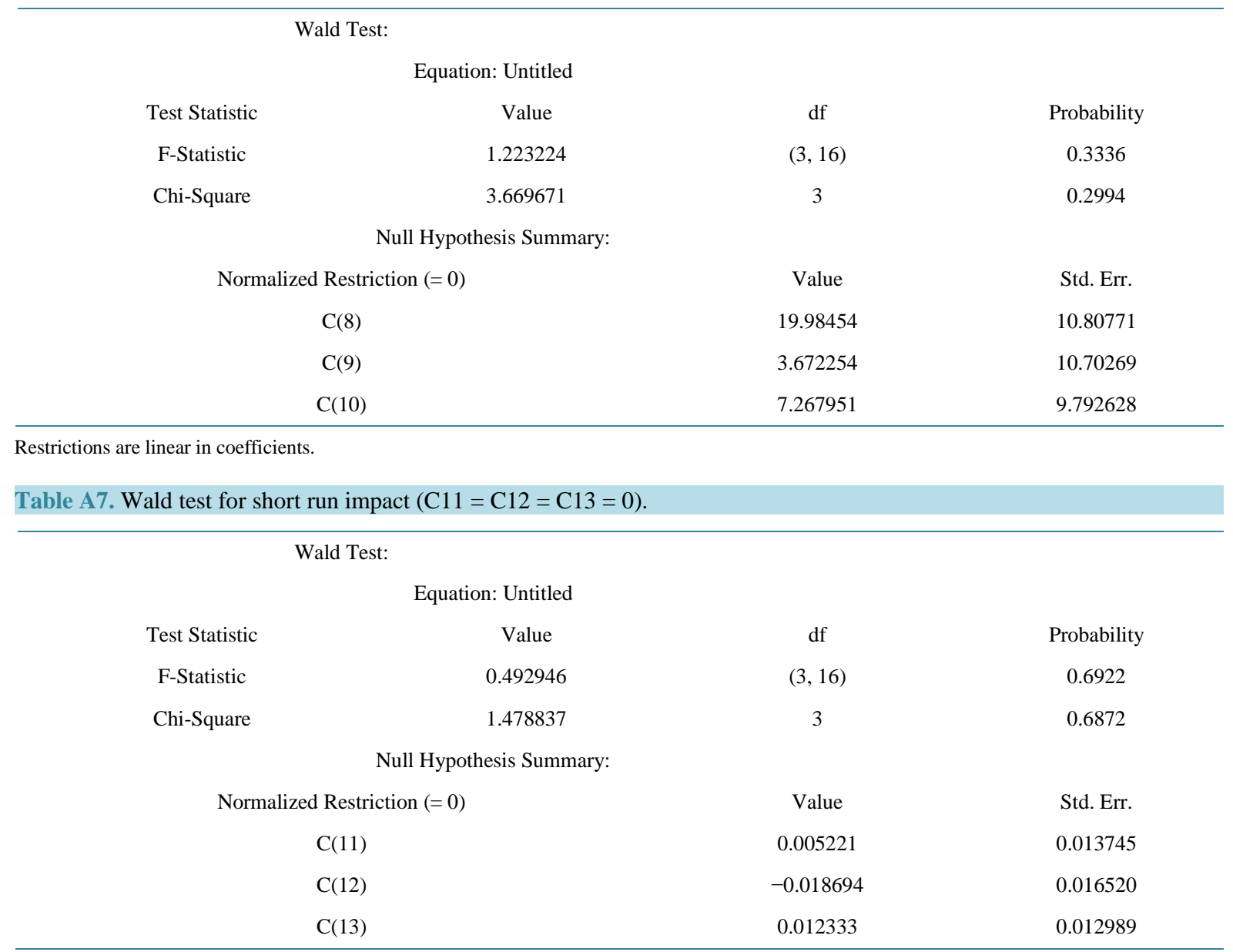

Restrictions are linear in coefficients. 
Scientific Research Publishing (SCIRP) is one of the largest Open Access journal publishers. It is currently publishing more than 200 open access, online, peer-reviewed journals covering a wide range of academic disciplines. SCIRP serves the worldwide academic communities and contributes to the progress and application of science with its publication.

Other selected journals from SCIRP are listed as below. Submit your manuscript to us via either submit@scirp.org or Online Submission Portal.
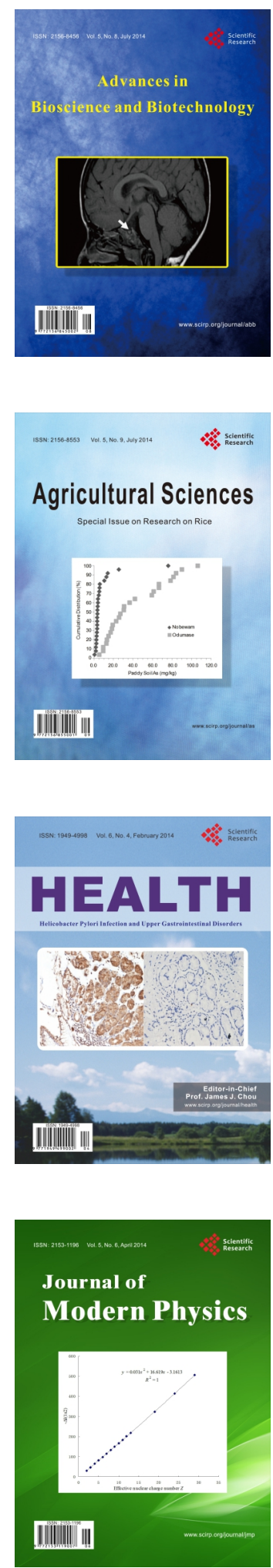
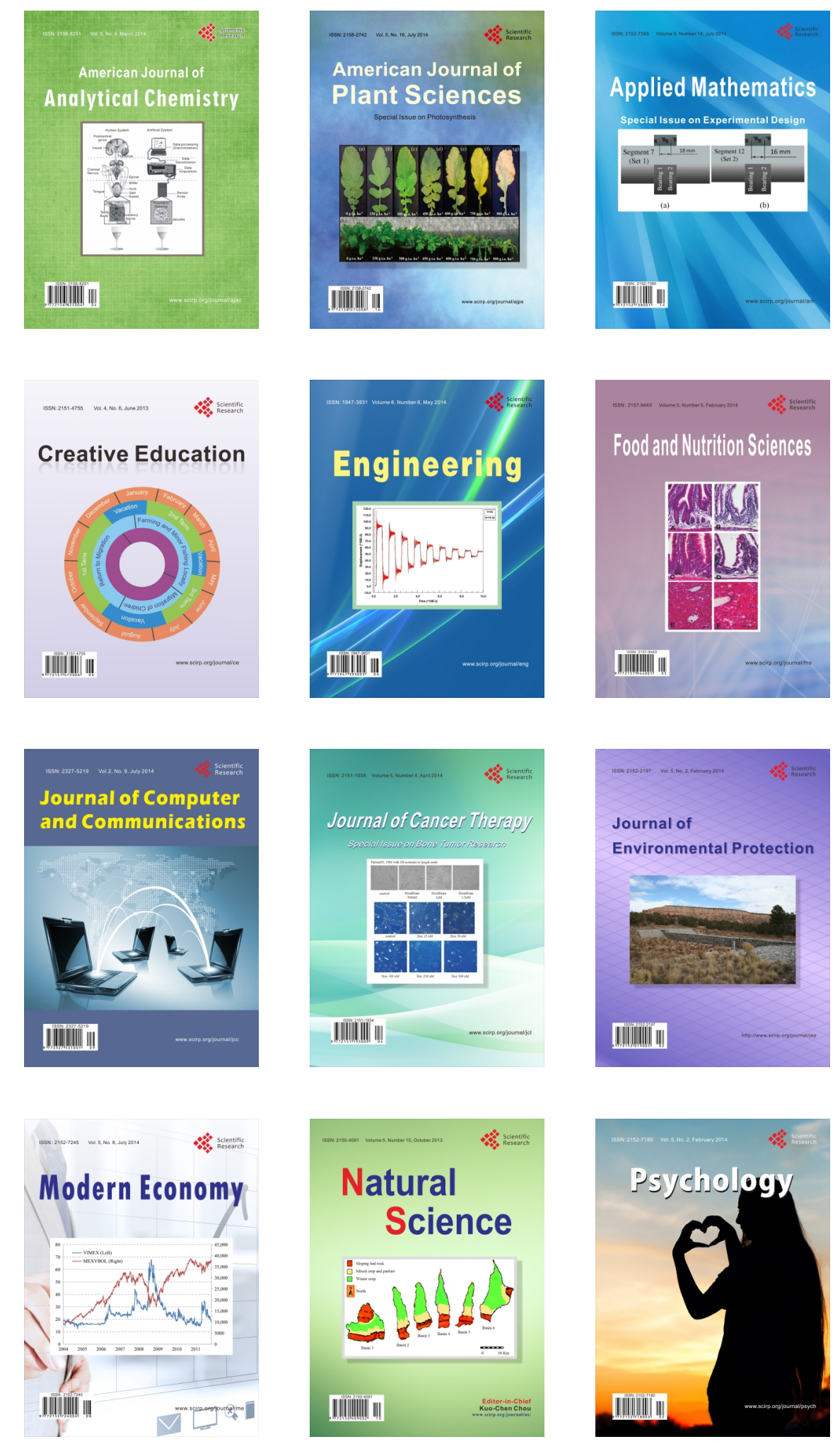